\title{
The Effect of Three Levels of Inquiry on the Improvement of Science Concept Understanding of Elementary School Teacher Candidates
}

\section{Putu Artayasa}

Doctoral Student, University of Mataram, Indonesia, artayasa75@yahoo.com

\section{Herawati Susilo}

Prof, State University of Malang, Indonesia, herawati.susilo.fmipa@um.ac.id

\section{Umie Lestari}

Dr, State University of Malang, Indonesia,umie.lestari.fmipa@um.ac.id

\section{Sri Endah Indriwati}

Dr, State University of Malang, Indonesia, sri.endah.fmipa@um.ac.id

This research aims to compare the effect of the implementation of three levels of inquiry: level 2 (structured inquiry), level 3 (guided inquiry), and level 4 (open inquiry) toward science concept understanding of elementary school teacher candidates. This is a quasi experiment research with pre-test post-test nonequivalent control group design. The population of the research was the students of Elementary School Teacher Education of University of Mataram who took the science education program. The sample of this research was 154 students taken by using cluster random sampling technique. The research instrument was a science concept test. The data were analyzed by using ANCOVA. The results showed that the implementation of open inquiry had the highest score of science concept understanding and was significantly different from the scores of the structured inquiry and guided inquiry and traditional strategy, while the scores of the structured inquiry, guided inquiry and traditional strategy were not significantly different. Thus, the conclusion of this research was that the implementation of open inquiry has a significant effect, while the implementation of structured and guided inquiry did not have a significant effect on the increase of science concept understanding of elementary school teacher candidates.

Keywords: levels of inquiry, science concept, structured inquiry, guided inquiry, open inquiry

Citation: Artayasa, I P. Susilo, H., Lestari, U., \& Indriwati, S. E. (2018). The Effect of Three Levels of Inquiry on the Improvement of Science Concept Understanding of Elementary School Teacher Candidates. International Journal of Instruction, 11(2), 235-248. https://doi.org/10.12973/iji.2018.11216a 


\section{INTRODUCTION}

Science concept understanding is defined as the students' cognitive ability in understanding and mastering the science concepts through a phenomenon, event, object, or activity related to the science material (Tursinawi, 2016). Science concept understanding is an important ability in mastering the essence of science (Mariana \& Praginda, 2009). Good science mastery is needed by human to solve the increasingly complex problems of science and technology in modern life (BSNP, 2010; Rahayu, 2016).

The teaching strategy of science concept understanding is generally carried out by giving examples and explaining the science concepts (Widiawati, Pudjawan, \& Margunayasa, 2015). However, the results of research on the science concept understanding of elementary school students in some regions of Indonesia are generally still low. Approximately 40-50\% of elementary school students under study have a science concept which is still in low category (Tursinawi, 2016; Widiawati et al., 2015). The weak science concept understanding of the students was also reflected on the results of the evaluation of the Program for International Student Assessment (PISA) from 2009 to 2015 on the science literacy of Indonesian students. The results showed that the score of the Indonesian students' science literacy was still below in the average of the countries evaluated (Kemendikbud, 2013; OECD, 2016).

Elementary school teachers and elementary school teacher candidates as people who teach science at elementary schools are expected to have a good understanding of science concepts to support their science teaching. However, the results of research in several regions in Indonesia, such as Gayo Lewes, Nanggroe Aceh Province and Ngada Regency in East Nusa Tenggara, show that the understanding of science concept of elementary school science teachers is still low (Laksana, 2014; Zulfadly, 2008). Nearly $50 \%$ of elementary school teachers and teacher candidates have misconceptions science materials (Laksana, 2016; Nahadi \& Hamdu, 2016; Pujayanto, 2011). Thus, the increase of the science concept understanding of elementary school science teachers and teacher candidates needs to be concerned to improve the performance of the science teaching in schools.

The level of the science concept understanding of the teachers cannot be separated from the learning process at the university where the teachers earned their titles (Akbar, 2010). In other words, the effectiveness of science learning process of the teacher candidates in the universities has an effect on the level of science concept understanding when they become teachers. Thus, it becomes a challenge for universities to look out for effective learning strategies to improve the science concept understanding of teacher candidates in order that they have good teaching science performance when they become teachers (Kurniawan \& Fadloli, 2016).

According to Skamp (1998), an effective science-learning strategy is by providing students with extensive opportunities to conduct independent investigations and to link the learning to their daily lives and environment. The science learning strategy is similar with the inquiry strategy, because according to Ketpichainarong, Panijpan, \& 
Ruenwongsa (2010), the implementation of inquiry strategy provides students with an opportunity to investigate science-based issues that they are interested in. This learning strategy is in accordance with the constructivist principles, which is to provide students with opportunities to construct new understandings based on their experiences by exploring various phenomena in their environment (Andrini, 2016).

Several research results show that the implementation of inquiry strategy has a significant effect on the improvement of students' understanding of science concept. The result of the study from Bilgin (2009), Ketpichainarong et al. (2010), Sahyar and Hastini (2017) indicate that students who implement inquiry strategy has better science concept understanding than those who implement traditional strategy. The implementation of the inquiry strategy also has an effect on the increase of students' motivation and science learning results (Abdi, 2014; Lintuan, Chin, Tsai, \& Cheng, 2005).

According to Llewellyn (2013), there are four levels of inquiry, namely demonstrated, structured, guided, and open inquiry (Table 1). The four levels of inquiry are distinguished by the amount of teachers' involvement in learning. Teachers' involvement decreases with the increasing inquiry level. The biggest teachers' involvement is in the demonstrated inquiry, and then it becomes less and less in structured, guided, and open inquiry.

Table 1

Characteristics of four levels of inquiry

\begin{tabular}{lllll}
\hline & $\begin{array}{l}\text { Demonstrated Structured } \\
\text { Inquiry } \\
\text { (Level 1) }\end{array}$ & $\begin{array}{l}\text { Inquiry } \\
\text { (Level 2) }\end{array}$ & $\begin{array}{l}\text { Guided } \\
\text { Inquiry } \\
\text { (Level 3) }\end{array}$ & $\begin{array}{l}\text { Self-directed or Student-Initiated } \\
\text { Inquiry (Open Inquiry) } \\
\text { (Level 4) }\end{array}$ \\
\hline Posing the question & Teacher & Teacher & Teacher & Student \\
\hline Planning the procedure & Teacher & Teacher & Student & Student \\
\hline Formulating the results & Teacher & Student & Student & Student \\
\hline
\end{tabular}

The research results show that the implementation of different levels of inquiry has an effect on the development of different capabilities. According to Sadah and Zion (2009) open inquiry students have a higher level of change criteria during inquiry (searching literatures, generating new ideas, solving technical problems) and understanding of work procedures. The research results show that the implementation of open inquiry is more effective in developing cognitive skills, procedural skills, and students' critical and scientific thinkings than that of the guided and structured inquiry (Zion \& Mendelovici, 2012). However, not all students can directly apply open inquiry. They still need a bridge before implementing a higher level of inquiry (Arslan, 2014). Other research results show that the implementation of open inquiry leads to higher psychomotor learning results but lower cognitive learning results than the implementation of guided inquiry (Sulistina, 2009).

Although there are four levels of inquiry with different characteristics and each of which can develop different abilities, to date, teachers generally only apply one level of inquiry within a learning period (Fuad, Zubaidah, Mahanal, \& Suarsini, 2017). According to 
Zion and Mendelovici (2012), there is still a controversy in determining which of the structured, guided, and open inquiries are the most effective to be implemented in schools. Therefore, to increase students' science concept understanding, it is needed information about inquiry levels and which one is more effective to be implemented in science learning. For testing which inquiry level is more effective, then the objective of this research is to examine the differences of the effects of the implementation of structured, guided, and open inquiry in increasing the science concept understanding of elementary school teacher candidates.

\section{METHOD}

\section{Research Design}

This is a quasi experimental research using pre-test post-test non-equivalent control group design. The population of this research was the third semester students of Elementary School Teacher Education (PGSD) of University of Mataram in the academic year 2016/2017. The sample consisted of 154 students divided into four classes, taken by cluster random sampling technique. The three classes were experimental groups consisting of structured, guided, and open inquiry classes, and the remaining class was the traditional class, which was used as the control group. Demonstrated inquiry strategy was not implemented in this research because all students from each class were expected to perform an experiment.

The research was conducted for three months in the science education lecture, starting from September to November 2016. The implementation of these three levels of inquiry was done gradually to provide adaptation phase for the guided and open inquiry students before they applied higher level of inquiry. In the first lesson, the three inquiry classes implemented the lowest level of inquiry, the structured inquiry. In the second lesson, the structured inquiry class still implemented the structured inquiry level, while the other two inquiry classes implemented a higher level of inquiry, namely the guided inquiry. In the third lesson and so on, the structured, guided, and open inquiry classes implemented the level of inquiry which corresponded to the name of each inquiry class.

In the learning process, all classes carried out experiments, but with different characteristics. The students in the structured inquiry class conducted experiments based on the experiment questions and work procedures made by the lecturers, while the students in the guided inquiry class were given experiment questions, but they were instructed to create their own work procedure. The open inquiry class carried out the experiment based on their experiment questions which they made by themselves, while the traditional class carried out the experiment based on the instructor's complete instructions, including the introduction, experiment questions, work procedures, and presentation of experimental data.

There were ten experiments conducted by the students when this research took place. The experiments were about measurements, substances and changes, plant diversity, photosynthesis, animal diversity, nutrition, respiration, circulation, pollution and adaptation, and simple machines. All experiment activities from traditional class and structured inquiry class were conducted in the class. Guided inquiry class and open 
inquiry class performed experiments inside the class and outside the class or at home. Two experiments were conducted inside the class. Three experiments were conducted in the class and then they were finished at home. And for the rest, five experiments were conducted outside the class. On each experiment, the students worked in groups of four to five. The class meetings were held weekly with 150 minutes for each meeting. One lecturer taught the four classes.

All the three inquiry classes implemented inquiry cycle based learning proposed by Llewellyn (2013). Each cycle of inquiry began with the stages of (1) inquisition, asking questions to be investigated, (2) acquisition, brainstorming possible answers to the questions, (3) supposition, selecting answers to the questions to be tested, (4) implementation, preparing the experimental work plans, (5) ) Summation, collecting data and drawing conclusions, and ended with (6) exhibition, communicating the experimental results (Table 2).

Table 2

The comparison of the students' activities on the three levels of inquiry and the traditional strategy

\begin{tabular}{|c|c|c|c|c|}
\hline $\begin{array}{l}\text { The stages in the } \\
\text { inquiry cycle }\end{array}$ & Structured inquiry & Guided inquiry & Open inquiry & Traditional \\
\hline Inquisition & $\begin{array}{l}\text { The lecturer asked } \\
\text { the experimental } \\
\text { questions }\end{array}$ & $\begin{array}{l}\text { The lecturer asked } \\
\text { the experimental } \\
\text { question }\end{array}$ & $\begin{array}{l}\text { Students asked the } \\
\text { experimental } \\
\text { questions }\end{array}$ & \multirow{6}{*}{$\begin{array}{l}\text { Students } \\
\text { carried out } \\
\text { activities } \\
\text { based on the } \\
\text { experimental } \\
\text { procedures } \\
\text { and } \\
\text { presented } \\
\text { their } \\
\text { experimental } \\
\text { results }\end{array}$} \\
\hline Acquisition & $\begin{array}{l}\text { The students } \\
\text { proposed various } \\
\text { possible answers to } \\
\text { the experimental } \\
\text { questions }\end{array}$ & $\begin{array}{l}\text { The students } \\
\text { proposed various } \\
\text { possible answers to } \\
\text { the experimental } \\
\text { questions }\end{array}$ & $\begin{array}{l}\text { Each group of } \\
\text { students discussed } \\
\text { the answers to the } \\
\text { questions they made }\end{array}$ & \\
\hline Supposition & $\begin{array}{l}\text { The student selected } \\
\text { the answers to be } \\
\text { tested in the } \\
\text { experiment }\end{array}$ & $\begin{array}{l}\text { The student } \\
\text { selected the answer } \\
\text { to be tested in the } \\
\text { experiment }\end{array}$ & $\begin{array}{l}\text { The student selected } \\
\text { the answer to be } \\
\text { tested in the } \\
\text { experiment }\end{array}$ & \\
\hline Implementation & $\begin{array}{l}\text { Students performed } \\
\text { experiments based } \\
\text { on experimental } \\
\text { work procedures }\end{array}$ & $\begin{array}{l}\text { Students } \\
\text { developed the } \\
\text { experimental work } \\
\text { procedures }\end{array}$ & $\begin{array}{l}\text { Students developed } \\
\text { the experimental } \\
\text { work procedures }\end{array}$ & \\
\hline Summation & $\begin{array}{l}\text { Students collected } \\
\text { and presented data } \\
\text { in tables or graphs } \\
\text { and drew } \\
\text { conclusions }\end{array}$ & $\begin{array}{l}\text { Students collected } \\
\text { and presented data } \\
\text { in tables or graphs } \\
\text { and drew } \\
\text { conclusions }\end{array}$ & $\begin{array}{l}\text { Students collected } \\
\text { and presented data } \\
\text { in tables or graphs } \\
\text { and drew } \\
\text { conclusions }\end{array}$ & \\
\hline Exhibition & $\begin{array}{l}\text { Students presented } \\
\text { the experimental } \\
\text { results }\end{array}$ & $\begin{array}{l}\text { Students presented } \\
\text { the experimental } \\
\text { results }\end{array}$ & $\begin{array}{l}\text { Students presented } \\
\text { the experimental } \\
\text { results }\end{array}$ & \\
\hline
\end{tabular}




\section{Data Collection and Analysis}

The data were collected from the scores of the pre-test and post-test of science concept understanding. The pre-test was carried out in the first week of the research, while the post-test was carried out at the end of the research that was the fourth week of November 2016. A total of 37 test items was used on the pre-test and post-test. The tests were made by the researchers and validated by two curriculum and science experts. The test items corresponded to the ten experimental topics. Types of the tests were multiple choice ( 35 items) and essay ( 2 items). In the multiple-choice test, the correct answer was given a score of 1 , while the wrong answer was given a score of 0 . The score of the essay answer was between 0 and 3. All the test items were valid $(p<.05)$. The coefficient of the Cronbach's alpha test was .86. Thus, it is declared as reliable (Sarwono, 2015).

The research was finished by performing an interview to three students from each researched class. The purpose of the interview was to get the data which were not recorded from test result. The question from the interview was about advantages and new things that they got from learning process. Therefore, the result of interview can give further explanation about test result and that is needed to enrich the research result discussion.

The data were analyzed by using Analysis of Covariance (ANCOVA). The ANCOVA prerequisite tests, namely the One-Sample Kolmogorov-Smirnov test was performed to determine the normality of the data and Levene test was performed to determine the homogeneity of the data variance. The post hoc Least Significant Difference (LSD) test was performed to determine the significance difference in the mean score of the four learning strategies implemented. The data analysis was performed on Statistical Package for Social Sciences (SPSS) for Windows version 22.

\section{FINDINGS}

The observation results of the experiments done by students show that on the topic of measurement and the topic of the substance and its changes, all classes had the same experimental questions. All the experimental questions were made by the lecturers, including on the open inquiry class on which they had not implemented an open inquiry strategy on both topics. However, when each class implemented different levels of inquiry, starting from the topic of plant diversity, the open inquiry class had more experimental questions than the other three classes. This was different from that in the structured and guided inquiry classes and traditional classes that had the same experimental questions, as shown in Table 3. 
Table 3

Comparison of the experimental questions between the open, guided, and structured inquiry and traditional classes

\begin{tabular}{|c|c|c|}
\hline \multirow[b]{2}{*}{$\begin{array}{l}\text { Experiment } \\
\text { topics }\end{array}$} & \multicolumn{2}{|l|}{ Experiment questions } \\
\hline & $\begin{array}{l}\text { Guided inquiry, } \\
\text { structured inquiry, } \\
\text { and traditional }\end{array}$ & Open inquiry \\
\hline Measurement & $\begin{array}{l}\text { 1. How is it to measure the width } \\
\text { and volume of regular and } \\
\text { irregular objects? }\end{array}$ & $\begin{array}{l}\text { How is it to measure the width and volume of regular and irregular } \\
\text { objects? }\end{array}$ \\
\hline $\begin{array}{l}\text { Substances and } \\
\text { changes }\end{array}$ & $\begin{array}{l}\text { 1. What is the difference between } \\
\text { solid, liquid and a gas? } \\
\text { 2. Between the physical and } \\
\text { chemical changes, which } \\
\text { changes are reversible and non- } \\
\text { reversible? }\end{array}$ & $\begin{array}{l}\text { What is the difference between a solid, liquid and a gas? } \\
\text { Between the physical and chemical changes, which changes are } \\
\text { reversible and non-reversible? }\end{array}$ \\
\hline Plant diversity & $\begin{array}{l}\text { 1. What is the difference between } \\
\text { monocotyl and dicotyl plant? }\end{array}$ & $\begin{array}{l}\text { What is the difference between monocotyl and dicotyl plant } \\
\text { morphology? } \\
\text { Is the transportation system between monocotyl and dicotyl different? } \\
\text { Is water absorption in plants affected by root, leaf or both? } \\
\text { Is the rate of water transport in plants different at different light } \\
\text { intensities? }\end{array}$ \\
\hline Photosynthesis & $\begin{array}{l}\text { What factors affect the rate of } \\
\text { photosynthesis? } \\
\text { 2. How is the experiment design to } \\
\text { prove that photosynthesis } \\
\text { produces oxygen and glucose? }\end{array}$ & $\begin{array}{l}\text { Does the difference in light intensity affect the number of oxygen gas } \\
\text { bubbles produced? } \\
\text { Does temperature difference affect the different rate of photosynthesis? } \\
\text { Can photosynthesis occur under the lights of lamps? } \\
\text { Is carbohydrate only produced from the leaves exposed by lights? }\end{array}$ \\
\hline Animal diversity & $\begin{array}{l}\text { 1. What are the different } \\
\text { characteristics of the structure of } \\
\text { invertebrates and vertebrates? }\end{array}$ & $\begin{array}{l}\text { What are the morphological characteristics of vertebrates and } \\
\text { invertebrates? } \\
\text { What is the position of invertebrates and vertebrates in the food web? } \\
\text { What are the characteristics of the animals which are susceptible to } \\
\text { extinct? } \\
\text { How is the animal grouping based on their habitat and food on } \\
\text { grassland ecosystems? }\end{array}$ \\
\hline Nutrition & $\begin{array}{l}\text { What substance is contained in } \\
\text { food and what is its function in } \\
\text { the body? }\end{array}$ & $\begin{array}{l}\text { What are the different characteristics of carbohydrates and fats? } \\
\text { Do our staple foods contain starch, protein, and glucose? } \\
\text { Do the drinks sold in packs contain vitamin C? }\end{array}$ \\
\hline Respiration & $\begin{array}{l}\text { 1. How to prove that carbon } \\
\text { dioxide and water vapor are } \\
\text { produced when we exhale? }\end{array}$ & $\begin{array}{l}\text { Is carbon dioxide produced when exhaling? } \\
\text { Is water vapor produced when exhaling? } \\
\text { What environmental factors act as a disturbance of the respiration of } \\
\text { aquatic animals? }\end{array}$ \\
\hline Circulation & $\begin{array}{l}\text { 1. Is there any effect of different } \\
\text { activity on the rate of pulse? }\end{array}$ & $\begin{array}{l}\text { What is the difference in pulse rate before and after exercise? } \\
\text { Does gender difference affect the pulse rate? } \\
\text { Does the weight difference affect the pulse rate? }\end{array}$ \\
\hline $\begin{array}{l}\text { Pollution and } \\
\text { adaptation }\end{array}$ & $\begin{array}{l}\text { 1. How is the effect of detergent } \\
\text { toward the responses of fish? } \\
\text { 2. Does the disguise of a butterfly's } \\
\text { body color function to save itself } \\
\text { from its predators? }\end{array}$ & $\begin{array}{l}\text { Does the presence of detergent affect the response of fish? } \\
\text { What is the effect of oil spills on fish behavior? } \\
\text { How are the adaptation differences of living things morphologically, } \\
\text { physiologically, and behaviorally? } \\
\text { What is the effect of environmental pollution on the adaptation of } \\
\text { living things? }\end{array}$ \\
\hline Simple machines & $\begin{array}{l}\text { 1. What are the types and } \\
\text { advantages of simple machines? }\end{array}$ & $\begin{array}{l}\text { What are the types of simple machines that exist in the domestic } \\
\text { environment? } \\
\text { How is the role of the inclined plane in daily life? } \\
\text { How do the differences in work result between work using and not } \\
\text { using simple machines? } \\
\text { What are the advantages of using a pulley? }\end{array}$ \\
\hline
\end{tabular}

International Journal of Instruction, April $2018 \bullet$ Vol.11, No.2 
The results of the science concept test show that the scores of the pre-test and post-test of the traditional class were the lowest, while the open inquiry class had the highest pretest and post-test scores followed by the guided and structured inquiry classes. The traditional class had an average pre-test score of 44.23 and post-test of 52.23, while the open inquiry class had 58.53 for the pre-test and 72.59 for the post-test (Table 4).

Table 4

The score of pre-test and post-test of science concept understanding

\begin{tabular}{lllccc}
\hline \multirow{2}{*}{ Strategy } & \multirow{2}{*}{$N$} & \multicolumn{2}{c}{ Pre-test } & \multicolumn{2}{c}{ Post-test } \\
\cline { 3 - 6 } & 36 & Mean & Std.Error & Mean & Std.Error \\
\hline Traditional & 44.23 & 2.32 & 52.23 & 2.23 \\
\hline Structured Inquiry & 41 & 45.97 & 2.37 & 54.79 & 2.70 \\
\hline Guided Inquiry & 39 & 54.41 & 1.93 & 64.10 & 2.33 \\
\hline Open Inquiry & 38 & 58.53 & 2.09 & 72.59 & 2.11 \\
\hline
\end{tabular}

Based on the Kolmogorov-Smirnov One-Sample test, both pre-test and post-test had significant values, $p=.200>.05$ so that the scores of both tests were normally distributed. Based on the homogeneity test, Levene test, the significant value for the pretest was .520 and the significant value for the post-test was .257 . Thus, the scores of both tests had homogeneous variance $(p>.05)$. The result of normality and homogeneity test has been fulfilled the parametric test assumption, which requires the normally distributed data and it has homogeneous variance prior to the use of ANCOVA.

The result of ANCOVA (Table 5) show that the levels of structured, guided, and open inquiry and traditional strategy have significantly different mean score, so that the results of this research indicate that there is an effect of the implementation of the three levels of inquiry toward the improvement of students' science concept understanding ( $F$ $=8.156, p=.000<.05)$. The results of this analysis also show that the pre-test scores have an effect on the post-test scores $(F=1011.863, p=.000<.05)$.

Table 5

ANCOVA Summary

\begin{tabular}{lrrrrr}
\hline Source & Type III Sum of Square & $d f$ & Mean Square & $F$ & \multicolumn{1}{c}{ Sig. $(p)$} \\
\hline pre-test & 28438.041 & 1 & 28438.041 & 1011.863 & .000 \\
\hline strategy & 687.685 & 3 & 229.228 & 8.156 & .000 \\
\hline
\end{tabular}

a. R Squared $=, 901$ (Adjusted R Squared $=, 899$ )

The results of post hoc LSD test (Table 6) show that the implementation of open inquiry has the highest effect on the increase of science concept understanding, and it is significantly different from the other three classes. Meanwhile, the structured inquiry, guided inquiry and traditional strategy have an effect which is not significantly different toward the increase of the students' science concept understanding. 
Table 6

LSD test summary

\begin{tabular}{|c|c|c|c|c|c|}
\hline Strategy (I) & Mean $^{a}$ & Strategy $(\mathrm{J})$ & $\begin{array}{l}\text { Mean } \\
\text { Difference (I-J) }\end{array}$ & $\begin{array}{l}\text { Std. } \\
\text { Error }\end{array}$ & $\begin{array}{l}\text { Sig. } \\
(p)\end{array}$ \\
\hline \multirow[t]{3}{*}{ Open Inquiry } & \multirow[t]{3}{*}{64,769} & Guided Inquiry & $4.321 *$ & 1.215 & .001 \\
\hline & & Structured Inquiry & $5.091 *$ & 1.259 & .000 \\
\hline & & Traditional & $5.890 *$ & 1.314 & .000 \\
\hline \multirow[t]{2}{*}{ Guided Inquiry } & \multirow[t]{2}{*}{60,448} & Structured Inquiry & .770 & 1.216 & .527 \\
\hline & & Traditional & 1.570 & 1.267 & 217 \\
\hline Structured Inquiry & 59,678 & Traditional & .799 & 1.212 & .511 \\
\hline Traditional & 58,878 & & & & \\
\hline
\end{tabular}

The results of interview indicate that the students of the traditional class and of the structured inquiry state that the experiment works are as a variation, in addition to the lecturing method, so that the learning process becomes more varied. The guided inquiry students state that an interactive atmosphere occurred during the experiment because the lecturer motivated the students to solve the experimental problems through intense questioning. Moreover, more specifically the open inquiry students state that the inquiry tasks encouraged the students to generate ideas, think critically and creatively to determine the experimental problems and work together to solve the problems.

\section{DISCUSSION}

Based on the results of the research, the implementation of open inquiry has a significant effect on the improvement of students' science concept understanding, and the results are significantly different from the implementation of structured and guided inquiry. In the learning process, the open inquiry students start their experiments by making experimental problems or questions, which are not done by the structured and guided inquiry and traditional strategy students. The consequence is to encourage the open inquiry students to have a high effort to find more literature and to provide more time to learn the science concepts to produce experimental questions. The process of studying the science concept has been done when they observed the phenomena as the basis of raising the experiment questions. This is in accordance with Sadeh and Zion (2009) that open inquiry students have higher levels of time preparation, literature searching, procedural comprehension, including the importance of controlling variables, work methods, and statistics, compared to the students implementing the other inquiry levels. The students who have higher efforts in learning will have higher knowledge scores (Schmid \& Bogner, 2015).

The number of the experimental questions generated by the open inquiry class is more than the other three classes, as shown in Table 3. The experimental questions are presented at the exhibition stage, thus providing an advantage to the open inquiry students to discuss more science concepts related to the experiment questions. The opportunities for the students to discuss more science questions will provide space for mutual correction and complementary information in order to gain a better 
understanding of the science concepts (Jablon, 2002; Rosenshine, 2012). The existence of more varied experimental questions also makes the discussion process more interesting, thus increasing the interaction and attractiveness of students in learning, and it is positively correlated with the students' concept understanding (Suprijono, 2014).

The characteristic of each level of inquiry, as Llewellyn (2013) suggests, is that teacher involvement in open inquiry compared to the other inquiry levels is the least of all, so that it gives greater responsibility for the students. The great involvement and responsibility will encourage the open inquiry students to think more critically, logically and creatively, so that they can fulfill the responsibilities of completing the experimental tasks. According to Zion and Mendelovici (2012), the implementation of open inquiry encourages the students to develop high-order thinking, such as critical thinking and logical thinking, creative thinking, and better inquiry skills. The critical, logical and creative thinking skill is correlated with cognitive skill and helps students gain a deeper understanding of the concepts they are learning (Koray \& Koksal, 2009).

The results of the interviews with the open inquiry students found that they were more challenged to generate experimental design ideas and were encouraged to make intense cooperation to get the experiments done properly. The results of these interviews were in accordance with the finding that the implementation of open inquiry trains the students to be more cooperative and increases their motivation in learning (Lintuan et al., 2005; Sadah \& Zion, 2011; Zion \& Mendelovici, 2012). The existence of good motivation and cooperation can lead to a pleasant learning atmosphere and give students a chance to have good and more effective behavior in learning (Aljaafreh, 2013), so that, it seems give effect to the level of science concept understanding of open inquiry students higher than that of the students of the other inquiry levels.

According to the results of this research, the mean score of the students' science concept understanding from structured, to guided, and to open inquiry increased from 59,678 to 60,448 , and to 64,769 . This result can be caused by the effect of the development of students' critical and scientific thinking skills that can contribute to the development of their science concept understanding. According to Zion and Mendelovici (2012) that there is a development of critical thinkings and scientific skills from structured to guided inquiry and to open inquiry. However, based on this research, the score difference between the structured and the guided inquiry was not statistically significant. The same result was also reported by Ramdani (2012) that the science achievement between structured and guided inquiry students was not significantly different, but both were significantly different from the open inquiry students. The similarities of the implementation between the structured and guided inquiry are that both classes are provided experimental questions by the lecturer (Llewellyn, 2013). The students' activities which are only based on the experimental questions provided by lecturers make the structured and guided inquiry students only study the science concept which is limited to the lecturers' questions. Thus, the two classes have a tendency to have the same score of the science concept understanding and they are different from the open inquiry students that require them to be more critical of the science concept they learn in order to find the experimental questions that will be tested in the experiment. 
In this research, although the structured inquiry students had higher mean score of science concept understanding than the traditional students, which was, 59,678 to 58,878 , but the difference was not significant. The implementation of structured inquiry and traditional strategy has similarities in terms of the experimental processes, both of which perform experiments based on the work procedures provided by lecturers, but they are different in terms of assigning responsibilities to the structured inquiry students to present the data in their own way (Llewellyn, 2011). This may have the same effect on their efforts in learning including to learn the concepts of science. Thus, this could be the reason that the effect of the implementation of structured inquiry on improving students' science concept understanding is not significantly different from that of the traditional strategy.

\section{CONCLUSION}

Based on the result of the research, it is concluded that the implementation of open inquiry has significant different effect with the implementation of structured and guided inquiry in improving students' science concept understanding. The implementation of structured and guided inquiry has the same effect with the implementation of traditional strategies in improving students' science concept understanding. Thus, the implementation of open inquiry is the best strategy in the effort to improve the science concept understanding of elementary school teacher candidates. The result of this research can provide implication to the curriculum development on the science lecturing of elementary school teacher candidate. For example, mini-research activities can be included to the curriculum. That is a way to facilitate the implementation of open inquiry strategy in science learning

The implementation of structured and guided inquiry in this research was based on one or two experimental questions on each of the experimental topics, and this was different from the open inquiry which had more experimental questions. The effect of the implementation of structured and guided inquiry can be re-evaluated with another research that gives students more diverse experimental questions. Thus, it is expected that more specific information found will help improve the effectiveness of the implementation of these two levels of inquiry in improving students' science concept understanding.

\section{REFERENCES}

Abdi, A. (2014). The effect of inquiry based learning method on student academic achievement in science course. Universal Journal of Education Research, 2(1), 37-41.

Akbar, B. (2010) Penguasaan keterampilan proses guru SD [Process skill mastery of elementary school teacher]. Jurnal Pendidikan dan Kebudayaan Educatio Indonesiae, 18/1, 1-16.

Aljaafreh, I. J. A. R. (2013). The effect of using the directed inquiry strategy on the development of critical thinking skills and achievement in physics of the tenth grade students in Southern Mazar. Journal of Education and Practice, 4(2)7, 191-197. 
Andrini, V. S. (2016). The effectiveness of inquiry learning method to enhance student' learning outcome: a theoretical and empirical review. Journal of Education and Practice, 7(3), 38-42

Arslan, A. (2014). Transition between open and guided inquiry instruction. Procedia Social and Behavioral Sciences, 141, $407-412$.

Bilgin, I. (2009). The effects of guided inquiry instruction incorporating a cooperative learning approach on university students' achievement of acid and bases concepts and attitude toward guided inquiry instruction. Scientific Research and Essay, 4/10, 10381046.

BSNP. (2010). Paradigma pendidikan nasional abad 21 [The national education paradigm of the 21st century]. Jakarta: Badan Standar Nasional Pendidikan.

Fuad, N. M., Zubaidah, S., Mahanal, S., \& Suarsini, E. (2017). Improving junior high schools' critical thinking skills based on test three different models of learning. International Journal of Instruction, 10(1), 101-116.

Jablon, P. (2002). Alignment of instruction with knowledge of student learning. In R. W. Bybee, Ed., Learning science and the science of learning, 65-76. Arlington, Virginia: National Science teachers association Press.

Kemendikbud. (2013). Implementasi kurikulum 2013 [Implementation of the 2013 curriculum]. Jakarta: Badan Pengembangan Sumber Daya Manusia Pendidikan dan Kebudayaan dan Penjaminan Mutu Pendidikan.

Ketpichainarong, W., Panijpan, B., \& Ruenwongsa, P. (2010). Enhanced learning of biotechnology students by an inquiry-based cellulose laboratory. International Journal of Environmental \& Science Education, 5(2), 169-187.

Koray, O., \& Koksal, M. S. (2009). The effect of creative and critical thinking based laboratory applications on creative and logical thinking abilities of prospective teachers. Asia-Pacific Forum on Science Learning and Teaching, 10/1, Retrieved 12 may, 2017 from https://www.ied.edu.hk/apfslt/download/v10_issue1_files/koksal.pdf

Kurniawan, A., \& Fadloli. (2016). Profil penguasaan keterampilan proses sains mahasiswa PGSD Universitas Terbuka [The profile of science process skill of PGSD students in Open University]. Proceeding Biology Education Conference, 13/1, 410419.

Laksana, D. N. L. (2014). Profil pemahaman konsep IPA guru-guru kelas sekolah dasar di Kabupaten Ngada NTT [The profile of science concept understanding of elementary school teachers in Ngada District NTT]. Jurnal Ilmiah Pendidikan Citra Bakti, 1(1), 1526.

Laksana, D. N.L. (2016). Miskonsepsi dalam Materi IPA Sekolah Dasar [Misconception in Elementary School Science Material], Jurnal Pendidikan Indonesia, 5(2), 843-852. 
Lintuan, H., Chin, C-C., Tsai, C-C, \& Cheng, S-F. (2005). Investigating the effectiveness of inquiry instruction on the motivation of different learning styles students. International Journal of Mathematic Education, 3, 541-566.

Llewellyn, D. (2011). Differentiated science inquiry. California: Corwin A Sage Company.

Llewellyn, D. (2013). Teaching high school science through inquiry and argumentation. (Second edition). California: Corwin A Sage Company.

Mariana, I. M. A., \& Praginda, W. (2009). Hakikat IPA dan pendidikan IPA untuk guru $S D$ [The nature of science and science education for elementary school teachers]. Jakarta: Pusat Pengembangan dan Pemberdayaan Pendidikan dan Tenaga Kependidikan IPA (PPPPTK IPA).

Nahadi \& Hamdu, G. (2016). Analisis pembelajaran IPA berbasis konteks dan assesment yang dikembangkan oleh mahasiswa calon guru sekolah dasar [Contextual and assessment-based science teaching analysis developed by prospective elementary school teachers], Seminar Nasional Pendidikan Sains, 41-47. Surakarta, 22 October, 2016.

OECD (2016). PISA 2015 PISA result in focus. Retrieved 25 August, 2016 from https://www.oecd.org.pdf.

Pujayanto (2011). Miskonsepsi IPA (fisika) pada guru sekolah dasar [The misconception of science (physics) in elementary school teachers], Jurnal Materi dan Pembelajaran Fisika, 1(1), 22-28.

Rahayu, S. (2016). Mengembangkan literasi sains anak Indonesia melalui pembelajaran berorientasi nature of science (NOS) [Developing Indonesian children science literacy through nature-based learning of science (NOS)]. Paper Presented at Professor inauguration speech, Universitas Negeri Malang, Indonesia, 17 March, 2016.

Ramdani, A. (2012). Pengembangan perangkat pembelajaran inkuiri melalui kegiatan lesson study serta pengaruhnya terhadap hasil belajar IPA biologi dan keterampilan berpikir kritis siswa berkemampuan akademik berbeda di SMPN Kota Mataram [Developing inquiry learning material through lesson study activities and its impact on biology science learning outcomes and critical thinking skills of different academic students at junior high school Kota Mataram]. Unpublished Dissertation, Pasca Sarjana Universitas Negeri Malang, Indonesia.

Rosenshine, B. (2012). Principles of instruction, research-based strategies that all teachers should know. American Educator, Retrieved 13 June, 2017 from https://www.aft.org/sites/ default/files/ periodicals/ Rosenshine.pdf.

Sadah, I., \& Zion, M. (2011). Which type of inquiry project do high school biology students prefer: open or guided? Res Sci Educ, 42, 831-848. 
Sadeh, I., \& Zion, M. (2009). The development of dynamic inquiry performance within an open inquiry setting: a comparison to guided setting. Journal of Research in Science Teaching, 46(10), 1137-1160.

Sahyar \& Hastini, F. (2017).The effect of scientific inquiry learning model based on conceptual change on physics cognitive competence and science process skill (SPS) of students at senior high school. Journal of Education and Practice, 8/5, 120-126.

Sarwono, J. (2015). SPSS 22. Yogyakarta: Penerbit ANDI.

Schmid, S. \& Bogner, F. X. (2015). Effects of students' effort scores in a structured inquiry unit on long-term recall abilities of content knowledge. Education Research International, Retrieved 13 June, 2017 from http://dx.doi.org/10.1155/2015/ 826734.pdf.

Skamp, K. (1998). Teaching Primary Science Constructively. C. MacKenzie, Ed., Victoria: Harcourt Australia Pty Ltd.

Sulistina, O. (2009). Keefektifan penggunaan metode pembelajaran inkuiri terbuka dan terbimbing dalam meningkatkan kualitas proses pembelajaran dan hasil belajar kimia siswa kelas X SMA Lab. Malang [The effectiveness of open and guided inquiry learning method in improving the learning process quality and chemistry learning results of class X Senior High School Lab students. Malang]. Unpublished Master's Thesis Pasca Sarjana Universitas Negeri Malang, Indonesia.

Suprijono, A. (2014). Cooperative learning. Yogyakarta: Pustaka Pelajar.

Tursinawi (2016). Penguasaan konsep hakikat sains dalam pelaksanaan percobaan pada pembelajaran IPA di SDN Kota Banda Aceh [Concept mastery of the nature of science in the implementation of experiments on science learning in Elementary School Kota Banda Aceh]. Jurnal Pesona Dasar, 2(4), 72-84.

Widiawati, N. P, Pudjawan, K. \& Margunayasa, I. (2015). Analisis pemahaman konsep dalam pelajaran IPA pada siswa kelas IV SD gugus II Kec. Banjar [Concept understanding analysis in science learning in fourth grade students of SD cluster II Kec. Banjar]. E-Journal PGSD Universitas Pendidikan Ganesha, 3/1, Retrieved 13 May, 2017 from ejournal.undiksha.ac.id/index.php/JJPGSD/article/download/.../422...pdf.

Zion, M. \& Mendelovici, R. (2012). Moving from structured to open inquiry: challenges and limits. Science Education International, 23/4, 383-399.

Zulfadly, S. S. (2008). Profil literasi sains dan teknologi guru matapelajaran IPA SD dan SMP serta hubungannya dengan prestasi belajar IPA siswa SD dan SMP di Kabupaten Gayo Lewes Provinsi Nanggro Aceh Darusalam (NAD) [Profile of science and technology literacy of science teacher in elementary and junior high schools and its relation with science achievement of elementary and junior high school students in Gayo Regency of Lewes Nanggro Aceh Darusalam Province (NAD)]. Jurnal Pendidikan Serambi Ilmu, 6(1), 25-28. 